\title{
GENETIC DIVERSITY OF MUTE SWAN POPULATION OF THE RIGA URBAN AREA
}

\author{
Agnese Kolodinska-Brantestam\#, Dmitrijs Boiko, Dace Grauda, Nikole Krasṇevska, \\ and Isaak Rashal \\ Institute of Biology, University of Latvia, Miera iela 3, Salaspils, LV-2169, LATVIA \\ \# Corresponding author; \\ agnese.kolodinska@bredband2.com
}

Contributed by Isaak Rashal

\begin{abstract}
Mute swan Cygnus olor is the most abundant breeding swan species in Riga and Latvia. Since manmade habitats are the preferred breeding habitats of this species - Cygnus olor is of particular interest in studies of urban biodiversity. The latest records show that 30-40 pairs breed annually in Riga, 400-700 individuals migrate through the area, and 120-150 individuals stay over winter. The goal of our study was to determine the genetic variation of the mute swan population in Riga. Blood samples were collected from 47 individual birds found in different sites in Riga or elsewhere in Latvia. The universal retrotransposon based iPBS markers were used to estimate diversity. Three primers $(2076,2080$, and 2415) amplified 64 DNA fragments; of these 18 (28\%) were polymorphic. The average diversity index based on polymorphic markers for the studied individuals was 0.425. All individuals, with the exception of two pairs of individuals, could be separated by means of these markers. The grouping of individuals was not be associated with their sampling location, gender and age. The genetic diversity indexes were compared between these groups. The breeding individuals (including their cygnets) had bands not showing variation among breeding birds as compared to the not breeding ones.
\end{abstract}

Key words: Cygnus olor, genetic variation, IRAP, retrotransposon-based molecular markers,

Breeding of mute swan (Cygnus olor) in Engure Lake in 1935 has been acknowledged as the first record of its breeding in Latvia (Transehe, 1939). A few decades later in 1964, 40 to 60 breeding pairs were recorded during bird inventory (Viksne, 1968). The inventory in 1974 reported 220 breeding pairs (Jõgi et al., 1976), and in the first breeding bird atlas of Latvia (Priednieks et al., 1989, pp. 94-95) 350 to 450 breeding pairs were reported in the period 1980-1984. In 2014, between 800 and 1000 breeding pairs have been recorded (www.putni.lv). Mute swans in Rīga comprise a small fraction. The first record of mute swan breeding in Rīga dates back to 1981 in Mašēnu Lake; a year later another pair was breeding in Vecdaugava (Strazds, unpublished dta). In territories adjacent to Rìga, mute swans began to breed significantly earlier - since 1956 in Babīte Lake, and since 1976 in fishponds in Upesciems (Lipsberg, 1979). Between 2010 and 2014, thirty to forty pairs were breeding in Rīga (Matrozis unpublished data.). Until 1970, only a few mute swans were observed wintering in Latvia (Lipsberg, 1979). Later the number of wintering individuals gradually increased (Stīpniece and Matrozis, 2001). Wintering mute swans have been observed near the Rìga Hydroelectric Power Plant since the early 1980s (Stipniece and Matrozis, 2001). The number of individuals varies depending on the year and is associated with severity of winter.
The average number overwintering individuals is 150 (Stīpniece and Matrozis, 2001). Since 1988, mute swans have changed their behaviour to accepting food from humans (Matrozis, 2012). Since 2002, migrating swans choose their stopover sites depending on human attitude to their feeding (Matrozis, 2012; Boiko, unpublished data). During migration, about 1000 individuals use supplementary food provided by humans (Matrozis, unpublished data). There is clear evidence that in Latvia the mute swan not only has been increasing in population size, but also that the species is using urban environments to a greater extent, bringing new challenges for species adaptability, which to some extent is genetically determined. The goal of our study was to determine the genetic variation of the mute swan population in Rīga.

In order to obtain blood samples, swans were attracted with bread and then caught by hand during breeding and migration periods from January of 2014 till February of 2015. In the breeding season (May - November), known breeding sites in Rìga were visited seven times to trap birds and collect blood samples. During migration (March - June and September - November), a stopover site near Ķengarags at the Daugava River was visited 18 times. During winter (December - February), 12 visits were made to the Dārzini area 
near the Rīga Hydroelectric Power Plant. In total, samples were collected at five sites in Rīga: Kengarags (56 $54^{\prime} 20^{\prime \prime} \mathrm{N}$ $\left.24^{\circ} 10^{\prime} 53^{\prime \prime} \mathrm{E}\right)$, Dārzini $\left(56^{\circ} 51^{\prime} 30^{\prime \prime} \mathrm{N} 24^{\circ} 17^{\prime} 08^{\prime \prime} \mathrm{E}\right)$, Vecmīlgrāvis $\left(57^{\circ} 01^{\prime} 39^{\prime \prime} \mathrm{N} 24^{\circ} 06^{\prime} 05^{\prime \prime} \mathrm{E}\right)$, Vecdaugava $\left(57^{\circ} 03^{\prime} 58^{\prime \prime} \mathrm{N}\right.$ $\left.24^{\circ} 05^{\prime} 53^{\prime \prime} \mathrm{E}\right)$, and Bolderāja $\left(57^{\circ} 02^{\prime} 18^{\prime \prime} \mathrm{N} 24^{\circ} 02^{\prime} 01^{\prime \prime} \mathrm{E}\right)$, and at a site in Suntaži, Ogre County $\left(56^{\circ} 54^{\prime} 12^{\prime \prime} \mathrm{N} 24^{\circ} 55^{\prime} 36^{\prime \prime} \mathrm{E}\right)$. The captured swans were sexed and aged. Unringed birds were ringed. Information about specimens carrying a ring was obtained from the respective ringing centers. Altogether, blood samples were taken from 47 individuals. Of them, 18 were females and 29 were males; among those, 14 were known to be breeding, 12 were migrating and 36 were wintering (Table 1). Blood was sampled from leg vein using syringes and plastic tubes and then stored in a freezer at $-20{ }^{\circ} \mathrm{C}$.

Total genomic DNA was extracted from 51 blood samples following the modified phenol-chloroform method (Eggert et al., 2005; Lazdiņš, unpublished). After supernatant removal $120 \mu$ of $5 \mathrm{M}$ potassium acetate (KOAc) was added for precipitation of impurities. In the last step DNA was treated with $5 \mu \mathrm{l}$ of RNase A (Fermantas) incubated for 10 minutes at $37{ }^{\circ} \mathrm{C}$.

Thirty-one LTR (long terminal repeat) retrotransposon based iPBS (inter-reverse transcriptase primer binding site) primers were tested (Kalendar et al., 2010), and of these three the most informative primers $(2080,2415,2076)$ were selected. The PCR was performed in a $25 \mu \mathrm{l}$ reaction mix consisting of $40 \mathrm{ng}$ DNA, DreamTaq buffer, $0.5 \mu \mathrm{l} \mathrm{dNTP}$ Mix, $0.5 \mu$ l primer $(34.8 \mathrm{nM}$ of primer $2080,112 \mathrm{mM}$ of primer 2076 and $26.9 \mathrm{nM}$ of primer 2415), $1.25 \mathrm{U}$ Dream Taq DNA polymerase and 0.0625 U Pfu DNA polymerase. The PCR program consisted of a first denaturation step of $95{ }^{\circ} \mathrm{C}$ for $3 \mathrm{~min}$ followed by 29 cycles $\left(95^{\circ} \mathrm{C}\right.$ for $30 \mathrm{~s}, 50$ ${ }^{\circ} \mathrm{C}$ for $40 \mathrm{~s}, 68{ }^{\circ} \mathrm{C}$ for $1 \mathrm{~min}$ ) and the last step at $72{ }^{\circ} \mathrm{C}$ for $10 \mathrm{~min}$. Amplification was performed in a GeneAmp PCR System 9700. The PCR products were separated on $1.7 \%$ agarose gel (TopVision agaroze, Fermentas) by means of electrophoresis during $17 \mathrm{~h}$ at $40 \mathrm{~V}$, stained with ethidium bromide. Fingerprints were captured by a digital camera and processed by „Totallab 1D” software.

PCR amplification products were scored as presence (1) or absence (0) of a fragment of a given length. The polymorphism information content (PIC) was used according to Anderson et al. (1992). NTSYS-pc software was used for calculation of the Jaccard similarity coefficient (Jaccard, 1908) and construction of an UPGMA (unweighted pair/group method with arithmetic averages) dendrogram as well as for Principal Coordinate Analysis (Rohlf, 1998).The diversity in whole sampled material and groups of individuals was estimated by means of the Shannon-Weaver diversity index (Hutchenson, 1970; King and Schaal, 1989).

In total, 64 PCR amplified fragments were scored, of which 18 were polymorphic. The average polymorphism information content (PIC) of the polymorph bands was 0.276 . The number of polymorphic bands per primer varied from five to six, and among these bands PIC varied from 0.042 to
Table 1

MUTE SWAN INDIVIDUAL CHARACTERISATION BY RING NUMBER AND BLOOD SAMPLING LOCATION

\begin{tabular}{|c|c|c|c|c|c|}
\hline No. & Ring No. & $\begin{array}{c}\text { Blood sampling } \\
\text { location }\end{array}$ & Sex* & Age** & Status*** \\
\hline 1 & EP170 & Dārziṇi, Rīga & M & 2 & $\mathrm{~W}$ \\
\hline 2 & EE639 & Ķengarags, Rīga & M & $\mathrm{ad}$ & $\mathrm{W}, \mathrm{M}$ \\
\hline 3 & EV552 & Dārziṇi, Rīga & M & 2 & $\mathrm{~W}$ \\
\hline 4 & EV561 & Ķengarags, Rīga & $\mathrm{F}$ & 2 & M \\
\hline 5 & EV553 & Dārziņi, Rīga & $\mathrm{F}$ & 2 & W \\
\hline 6 & EP176 & Dārzini, Rīga & M & 2 & W \\
\hline 7 & EV555 & Ķengarags, Rīga & $\mathrm{M}$ & 2 & $\mathrm{~W}$ \\
\hline 8 & EP160 & Dārziṇi, Rīga & $\mathrm{F}$ & 2 & $\mathrm{~W}$ \\
\hline 9 & EK976 & Dārziņi, Rīga & M & $\mathrm{ad}$ & W \\
\hline 10 & EP185 & Dārzini, Rīga & $\mathrm{M}$ & 3 & W \\
\hline 11 & EP179 & Dārziņi, Rīga & M & 2 & W \\
\hline 12 & EK900 & Dārziṇi, Rīga & M & $\mathrm{ad}$ & $\mathrm{B}, \mathrm{W}$ \\
\hline 13 & EE117 & Ķengarags, Rīga & $\mathrm{F}$ & $\mathrm{ad}$ & $\mathrm{B}, \mathrm{W}$ \\
\hline 14 & EM864 & Dārziṇi, Rīga & M & $\mathrm{ad}$ & $\mathrm{W}, \mathrm{M}$ \\
\hline 15 & EP101 & Dārziṇi, Rīga & $\mathrm{F}$ & 2 & W \\
\hline 16 & EP189 & Dārziņi, Rīga & M & 2 & W \\
\hline 17 & EM815 & Ķengarags, Rīga & $\mathrm{F}$ & $\mathrm{ad}$ & $\mathrm{W}$ \\
\hline 18 & EE154 & Dārziṇi, Rīga & M & ad & W \\
\hline 19 & EE168 & Dārzini, Rīga & $\mathrm{F}$ & $\mathrm{ad}$ & $\mathrm{B}, \mathrm{W}$ \\
\hline 20 & EP169 & Dārziņi, Rīga & M & 2 & $\mathrm{~W}$ \\
\hline 21 & EV650 & Dārziņi, Rīga & $\mathrm{F}$ & 2 & $\mathrm{~B}, \mathrm{~W}$ \\
\hline 22 & EP083 & Ķengarags, Rīga & M & ad & M \\
\hline 23 & EE006 & Dārziņi, Rīga & M & $\mathrm{ad}$ & $\mathrm{B}, \mathrm{W}$ \\
\hline 24 & EV557 & Ķengarags, Rīga & $\mathrm{F}$ & ad & M \\
\hline 25 & EV556 & Ķengarags, Rīga & M & 2 & $\mathrm{~W}, \mathrm{M}$ \\
\hline 26 & EP181 & Ķengarags, Rīga & $\mathrm{F}$ & 3 & W \\
\hline 27 & EP166 & Dārzini, Rīga & $\mathrm{F}$ & 2 & W \\
\hline 28 & CT52 & Dārziņi, Rīga & M & $\mathrm{ad}$ & $\mathrm{W}, \mathrm{M}$ \\
\hline 29 & EK896 & Ķengarags, Rīga & M & $\mathrm{ad}$ & M \\
\hline 30 & EP111 & Ķengarags, Rīga & $\mathrm{F}$ & $\mathrm{ad}$ & M \\
\hline 31 & EP355 & Ķengarags, Rīga & $\mathrm{F}$ & $\mathrm{ad}$ & M \\
\hline 32 & EK972 & Ķengarags, Rīga & M & $\mathrm{ad}$ & W \\
\hline 33 & AH4205 & Ķengarags, Rīga & M & $\mathrm{ad}$ & $\mathrm{W}$ \\
\hline 34 & EV741 & Ķengarags, Rīga & $\mathrm{F}$ & $\mathrm{ad}$ & W \\
\hline 35 & EV968 & Dārziṇi, Rīga & M & $\mathrm{ad}$ & W \\
\hline 36 & EV742 & Dārziņi, Rīga & $\mathrm{F}$ & 2 & W \\
\hline 37 & EV646 & Ķengarags, Rīga & M & $\mathrm{ad}$ & $\mathrm{W}$ \\
\hline 38 & EK113 & Bolderāja, Rīga & M & $\mathrm{ad}$ & B \\
\hline 39 & EE462 & Vecmīlgrāvis, Rīga & $\mathrm{F}$ & ad & $\mathrm{B}, \mathrm{M}$ \\
\hline 40 & EV942 & Ķengarags, Rīga & M & 1 & $\mathrm{~B}, \mathrm{~W}$ \\
\hline 41 & EV734 & Vecdaugava, Rīga & M & 1 & B \\
\hline 42 & EP287 & Ķengarags, Rīga & M & ad & M \\
\hline 43 & EV735 & Ķengarags, Rīga & M & 1 & $\mathrm{~B}, \mathrm{~W}$ \\
\hline 44 & EV736 & Ķengarags, Rīga & $\mathrm{F}$ & $1 \mathrm{y}$ & $\mathrm{B}, \mathrm{W}$ \\
\hline 45 & EE593 & Suntaži, Ogres nov. & M & ad & B \\
\hline 46 & EV740 & Ķengarags, Rīga & $\mathrm{F}$ & 1 & $\mathrm{~B}, \mathrm{~W}$ \\
\hline 47 & EV954 & K̦engarags, Rīga & M & 1 & $\mathrm{~B}, \mathrm{~W}$ \\
\hline
\end{tabular}

* Sex: M - male, F - female; ** age: 1 - first year bird, 2 - second-year bird, 3 - third year bird, ad - adult bird (age unknown); ***status: B breeding, W - wintering, M - migrating 
IPBS MARKER POLYMORPHISM IN STUDIED MUTE SWANS

\begin{tabular}{c|c|c|c|c}
\hline $\begin{array}{c}\text { Primer } \\
\text { No. }\end{array}$ & $\begin{array}{c}\text { Total number } \\
\text { of band scored }\end{array}$ & $\begin{array}{c}\text { Number of } \\
\text { polymorph } \\
\text { bands }\end{array}$ & $\begin{array}{c}\text { Range of PIC } \\
\text { of polymorph } \\
\text { bands }\end{array}$ & $\begin{array}{c}\text { Average PIC } \\
\text { among } \\
\text { polymorph } \\
\text { bands }\end{array}$ \\
\hline 2076 & 18 & 7 & $0.042-0.494$ & 0.253 \\
2080 & 25 & 6 & $0.042-0.500$ & 0.300 \\
2415 & 21 & 5 & $0.081-0.449$ & 0.282
\end{tabular}

PIC, polymorphism information content

0.500 (Table 2). The average diversity index for the studied group of individuals was 0.425 . The values of diversity indexes and number of polymorphic bands detected in various subgroups of studied birds are shown in Table 3. Jaccard similarity index among the differentiated individuals varied from 0.807 to 0.981 . There were two pairs of individuals having identical band patterns and hence could not differentiated my means of these markers.

The individuals could clearly be differentiated by means of the used markers, with the exception of two groups with two individuals in each: EV785 and EE168; and EM864 and EP185 (Fig. 1).

No segregation of the studied individuals based on their gender, sampling location or age could be demonstrated (data not shown). Differences were observed for the diversity distribution of birds that were nesting (breeding) and their cygnets vs. the non-nesting ones (Fig. 2).
GENETIC DIVERSITY OF MUTE SWANS, DIFFERENCES OF DIVERSITY BETWEEN GROUPS OF INDIVIDUALS DEPENDING ON GENDER, AGE, LOCATION AND STATUS

\begin{tabular}{|c|c|c|c|c|c|}
\hline \multicolumn{2}{|c|}{ Group of individuals } & $\begin{array}{c}\text { Number of } \\
\text { individu- } \\
\text { als }\end{array}$ & $\begin{array}{l}\text { Average } \\
\text { diversity } \\
\text { index }\end{array}$ & $\begin{array}{c}\text { Number of } \\
\text { polymorph } \\
\text { bands }\end{array}$ & $\begin{array}{c}\text { Range of } \\
\text { diversity } \\
\text { index per } \\
\text { polymorph } \\
\text { band }\end{array}$ \\
\hline \multicolumn{2}{|c|}{ All individuals } & 47 & 0.425 & 18 & $0.103-0.691$ \\
\hline \multirow[t]{2}{*}{ Status } & $\begin{array}{l}\text { Breeding } \\
\text { (nesting) and } \\
\text { their cygnets }\end{array}$ & 14 & 0.369 & 15 & $0.257-0.683$ \\
\hline & $\begin{array}{l}\text { Not breeding (not } \\
\text { nesting) }\end{array}$ & 33 & 0.408 & 15 & $0.136-0.689$ \\
\hline \multirow[t]{2}{*}{ Gender } & Females & 18 & 0.445 & 17 & $0.215-0.690$ \\
\hline & Males & 29 & 0.398 & 16 & $0.150-0.692$ \\
\hline \multirow[t]{2}{*}{ Age } & $\begin{array}{l}\text { One to three } \\
\text { years old }\end{array}$ & 23 & 0.409 & 17 & $0.136-0.693$ \\
\hline & Adult birds & 24 & 0.406 & 16 & $0.173-0.650$ \\
\hline \multicolumn{2}{|c|}{ Location* Dārziņi, Rīga } & 21 & 0.380 & 15 & $0.191-0.692$ \\
\hline & Ķengarags, Rīga & 22 & 0.426 & 16 & $0.185-0.693$ \\
\hline
\end{tabular}

* Only the largest two groups of individuals from different sites were included

Transposable elements (TEs) are known to be powerful agents of evolutionary change. Despite the fact that retrotransposon activity (retrotransposition's) can have a negative effect via gene disruption resulting in diseases and disorders, they can also be beneficial as a major source of

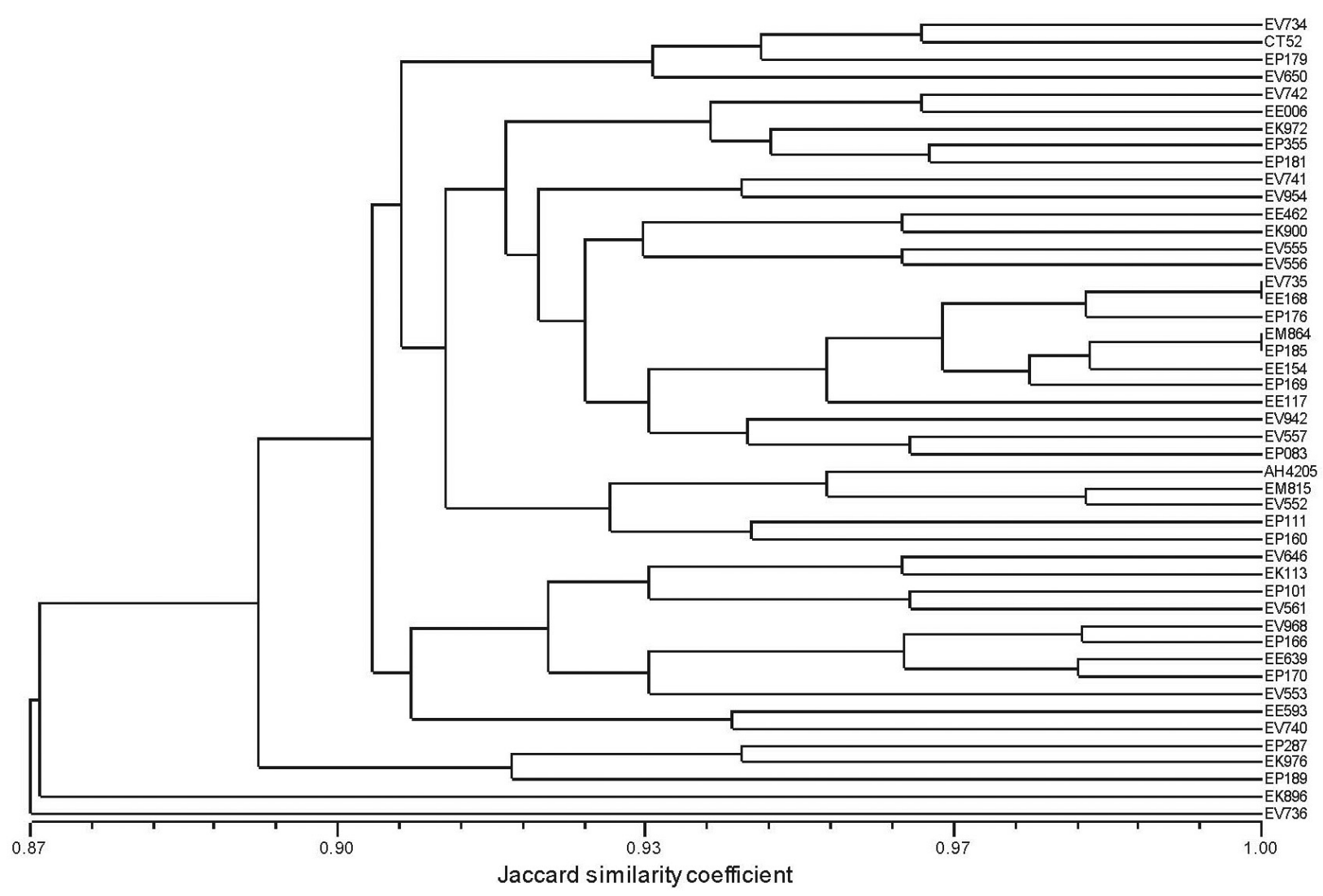

Fig. 1. UPGMA dendrogram based on Jaccard similarity coefficient calculated by distribution of iPBS markers among swan individuals. 
DIVERSITY INDEXES FOR DIFFERENT BANDS IN GROUPS OF BREEDING (NESTING) AND NOT BREEDING (NOT NESTING) SWANS

\begin{tabular}{|c|c|c|c|c|c|c|c|c|c|c|c|c|c|c|c|c|c|c|}
\hline Group & 2080_3 & 2080_6 & 2080_10 & 2080_12 & $2080 \_15$ & 2080_24 & 2415_3 & 2415_11 & $2415 \_12$ & 2415_17 & $2415 \_21$ & 2076_1 & 2076_4 & 2076_5 & 2076_9 & 2076_10 & 2076_13 & 2076_18 \\
\hline $\begin{array}{l}\text { Not } \\
\text { breed- } \\
\text { ing }\end{array}$ & 0.000 & 0.410 & 0.520 & 0.598 & 0.652 & 0.410 & 0.683 & 0.410 & 0.410 & 0.410 & 0.598 & 0.000 & 0.000 & 0.683 & 0.257 & 0.257 & 0.410 & 0.683 \\
\hline $\begin{array}{l}\text { Breed- } \\
\text { ing }\end{array}$ & 0.136 & 0.136 & 0.425 & 0.689 & 0.682 & 0.586 & 0.613 & 0.369 & 0.369 & 0.000 & 0.637 & 0.305 & 0.425 & 0.613 & 0.000 & 0.000 & 0.670 & 0.689 \\
\hline
\end{tabular}

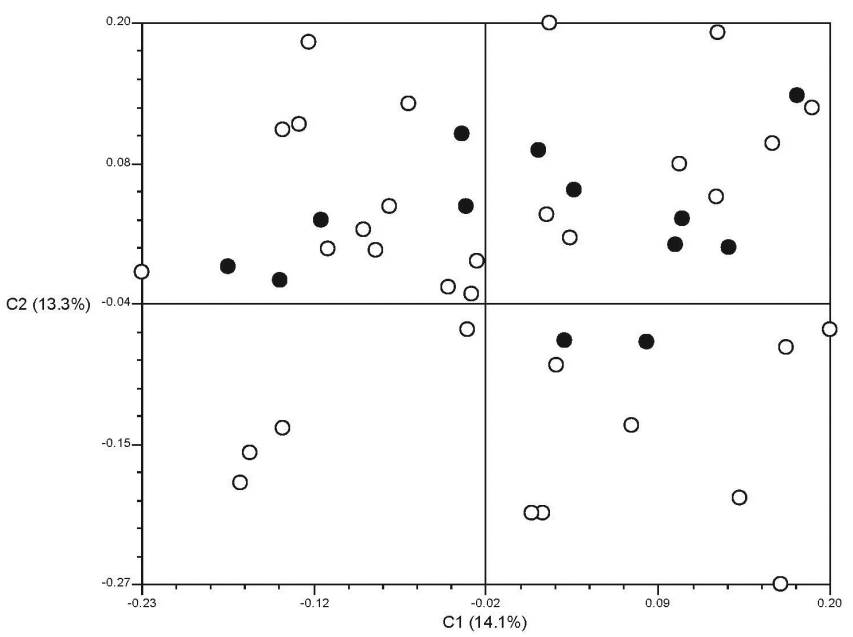

Fig. 2. Distribution of swan individuals with different breeding status according to Principal Coordinate Analysis.

(•) - breeding (nesting) individuals

(o) - non-breeding (not-nesting) individuals

regulatory and coding sequences for genetic innovation. Retrotransposons have a potential role in the regulation of gene silencing and have been shown to prevent changes in DNA-methylation at gene promoters, thus precluding changes in gene expression (Estecio et al., 2010). Zeh et al. (2009) suggested that increases in transposable element activity in response to physiological stress may provide the foundation for the punctuated equilibrium model of evolutionary change. Hence, organisms have evolved to support a balance between retrotransposition insertions. The nature of transposable elements and their role in species adaptation suggested that retrotransposon based markers would be a relevant choice for studying species diversity exposed to challenge of adaptation to the urban environment. The iPBS markers used in this study revealed variation within the group of mute swans in Rìga and Latvia. The three primers used allowed to separate the majority of individuals studied. Our findings disagree with results of a study by Butkauskas et al. (2012) based on partial mitochondrial D-loop sequences, as they found only one haplotype in mute swans breeding and wintering in Latvia and Lithuania suggesting monotypic genetic structure. This discrepancy might be explained by the different methods used: in the study of Butkauskas et al. (2012) diversity acquired via maternal inheritances was analysed, whereas our data involves nuclear variability of individuals.

Based on the iPBs markers the average genetic diversity did not differ significantly between breeding individuals (in- cluding their cygnets) and non-breeding birds in Rīga (Table 3). However, there were three bands (2415_17; 2078_9; 2078_10) not showing variation among breeding birds, in contrast to variation among non-breeding ones (Table 4). A somewhat decreased variation was visualized in the PCOORD. The non-breeding individuals were found in all four quadrants of PCOORD whereas the breeding ones only in three quadrants (Fig. 2). It would be interesting to determine amplification products of these three bands in order to establish DNA sequences. Are these sequences related to adaptive advantage for breeding/nesting in the northern distribution area of mute swans and/or highly populated urban area? Further studies to test this hypothesis using populations breeding/nesting in more southern locations and in areas with less urban pressure shall be carried out. In further studies we need also to consider that retrotransposons can be active during development. For example, environmental (e.g. stress) and internal (e.g. hormones) factors have been found to activate LINE-1 retrotranspositions in humans, and this mechanism for the generation of genetic variations potentially can be important for individual adaptability (Singer et al., 2010).

\section{ACKNOWLEDGEMENTS}

The study was financially supported by the European Social Fund, the project No. 2013/0060/1DP/1.1.1.2.0/13/APIA/ VIAA/041.

\section{REFERENCES}

Anderson, J. A., Churchill, G. A., Autriwue, J. E., Tanksley, S. D., Sorrells M. E. (1992). Optimizing parental selection for genetic linkage maps. Genome, 36,181-186.

Butkauskas, D., Švažas, S., Tubelytė, V., Morkūnas, J., Sruoga, A., Boiko, D., Paulauskas, A., Stanevičus, V., Baublys V. (2012). Coexistence and population genetic structure of the whooper swan Cyngus cyngus and mute swan Cyngus olor in Lithuania and Latvia. Central Eur. J. Biol., 7 (5), 886-894.

Eggert, L. S., Maldonado, J. E., Fleischer, R. C. (2015). Nucleic acid isolation from ecological samples - animal scat and other associated materials. In: Zimmer, E. A., Roalson, E. (eds.). Methods in Enzymology. Vol. 395. Molecular Evolution: Producing the Biochemical Data. Part B. Elsevier Academic Press, 896 pp.

Estecio, M. R., Gallegos, J., Vallot, C., Castoro, R. J., Chung, W., Maegawa, S., Oki, Y., Kondo, Y., Jelinek, J., Shen, L., Hartung, H., Aplan, P. D., Czerniak, B. A., Liang, S., Issa, J. P. (2010). Genome architecture marked by retrotransposons modulates predisposition to DNA methylation in cancer. Genome Res., 20, 1369-1382.

Jaccard, P. (1908). Nouvelles rescherches sur la distribution florale. Bull. Soc. Vaud. Sci. Nat., 44, 223-270. 
Jõgi, A., Lipsberg, J., Nedzinskas, V. (1976). Number and sesonal distribution of East-Baltic population of mute swan [Йыги А., Липсберг Ю, Недзинскас В. Численность и сезонное размещение ВосточноПрибалтийской популяции лебедя-шипуна]. In: Birds Migration [Миграции птии]. Valgus, Tallinn, pp. 175-184 (in Russian).

Kalendar, R., Antonius, K., Smykal, P., Schulman A. H. (2010). iPBS: a universal method for DNA fingerprinting and retrotransposon isolation. Theor. Appl. Genet., 121 (8), 1419-1430.

Kyle, R., Uptona, J., Bailliea K., Faulknera G. J. (2015). Is somatic retrotransposition a parasitic or symbiotic phenomenon? Mob. Gen. Elements, 1, (4), 279-282.

Lipsberg, J. (1979). Number and distribution of mute swan in Latvia [Липсберг Ю. Численность и распространение лебедя-шипуна в Латвии]. Ornitologiya, 14, 26-132 (in Russian).

Matrozis, R. (2012). Development of traditions of swan supplementary feeding in Latvia [Gulbju piebarošanas tradīcijas attīstība Latvijā]. Putni Dabā, Nr. 3-4, 42-47 (in Latvian).

Priednieks, J., Strazds, M., Strazds, A., Petrinš, A. (1989). Breeding Bird Atlas of Latvia: 1980-1984 [Latvijas ligzdojošo putnu atlants: 1980-1984]. Zinātne, Rīga. 352 pp. (in Latvian).

Rohlf, M. (1998). NTSYS-pc: Numerical Taxonomy and Multivariate Analysis System. Version 2.1. Department of Ecology and Evolution. State University of New York.
Singer, T., McConnell, M. J., Marchetto, M. C., Coufal, N. G., Gage, F. H. (2010). LINE-1 retrotransposons: Mediators of somatic variation in neuronal genomes? Trends Neurosci., 33, 345-354.

Sneath, P. H., Sokal, R. M. (1973). Numerical Taxonomy: The Principles and Practice of Numerical Classification. Freeman W. H. \& Co., San Francisco. $573 \mathrm{pp}$.

Stīpniece, A., Matrozis, R. (2001). The mute swan (Cygnus olor) wintering in Latvia (1984 - 2001). Acta Biol. Univ. Daugavpilensis, 1, 45-50

Transehe, N. (1939). Hockerschwane (Cygnus olor) als Brutvogel des Engures-Sees. Korrespondenzblatt der Naturforschen Vereins zu Riga, 58, $39-41$.

Viksne, J. (1968). Results of recording of mute swan and white-tailed eagle in Latvia in 1964. [Виксне Я. Результаты учетов лебедя-шипуна и орлана-белохвоста в Латвии в 1964 году]. Reports of Baltic Commission of Research of Birds Migration [Сообщения Прибалтийской комиссии по изучению миграций птиц], 5, 76-80 (in Russian).

Wolf, C., Linden, D. E. J. (2012). Biological pathways to adaptability: Interactions between genome, epigenome, nervous system and environment for adaptive behaviour. Genes, Brain Behav., 11 (1), 3-28

Zhang, J., Peterson T. (2004). Transposition of reversed Ac element ends generates chromosome rearrangements in maize. Genetics, 167, 1929-1937.

Received 5 May 2015

\section{PAGURKNĀBJA GULBJU RĪGAS POPULĀCIJAS G̦ENĒTISKĀS DAUDZVEIDĪBA}

Paugurknābaja gulbji Cygnus olor ir viena no biežāk sastopamajām gulbju sugām Latvijā, t.sk. arī Rīgā. Tā kā šì suga labprāt ligzdo cilvēka veidotā vidē, tā raisa îpašu interesi urbānās vides bioloǵiskās daudzveidības pētniekiem. Rīgas teritorijā pēdējā laikā ligzdo 30-40 gulbju pāri, 400-700 gulbju apstājas pilsētas ūdenskrātuvēs migrācijas laikā, un 120-150 gulbju ziemo Rīgas teritorijā. Pētỉjuma mērḳis bija noteikt Rīgas paugurknābja gulbju populācijas ġenētisko daudzveidību. Tika pētītas 47 gulbju genētiskās atškirības. G̣enētiskās daudzveidības analīzes veikšanai tika izmantota universālā, uz retrotranspozoniem balstîtā iPBS metode. Izvēlētie trīs polimorfi praimeri deva iespēju atšķirt visu pētīto indivīdu (izņemot vienu pāri) genotipus. Indivīdu ǵenētiskā radniecība nebija saistīta ar dzimumu un vecumu, kā arī ar paraugu ievākšanas lokalizāciju. Dažas ǵenētiskās mainības īpatnības tika konstatētas, salīdzinot ligzdojošos un neligzdojošos putnus. 